\title{
PENGAWASAN TINDAK PIDANA KORUPSI PADA DINAS PENDIDIKAN KABUPATEN TANGERANG
}

\author{
Dasrizal \\ Fakultas Hukum Universitas pamulang \\ E-mail: dasrizal@Gmail.com
}

\begin{abstract}
Pengawasan yang dilakukan Dinas pendidikan Kabupaten Tangerang untuk Mencegah tindak pidana korupsi di Lembaga Pendidikan tetap berdasarkan pada Pasal 66 Undang-Undang Nomor 20 Tahun 2003 tentang Sistem Pendidikan Nasional pelaksanaan dari pengawasan tersebut dilaksanakan dengan Peraturan Pemerintah dan Peraturan Pemerintah Daerah (PEMDA) di samping itu Dinas Pendidikan Kabupaten Tangerang juga menjalankan pengawasan horizontal, pengawasan Vertikal, pengawasan Eksternal, pengawasan Internal, pengawasan preventif, pengawasan a-Priori, pengawasan a-Posteriori, serta prinsip-prinsip dari pengawasan serta melaksanakan sistem pengawasan. yang dijalankan terus menerus dalam pelaksanaan tugas-tugas kegiatan di Dinas Pendidikan Kabupaten Tangerang. Dengan adanya keterbatasan. Peraturan perundang-undangan yang mengatur Tindak Pidana Korupsi di bidang pendidikan, sementara semakin berkembangnya, kuantitas dan kualitas tindak pidana pendidikan, maka penulis perlu menyarankan pada Pemerintah dan DPR. Untuk membuat undang-undang khusus tentang tindak pidana korupsi di bidang pendidikan. Dalam pembuatan undang-undang tersebut. Dengan ikut memperdayakan pakar-pakar hukum dari Perguruan Tinggi dan kalangan pakar hukum lainnya serta mengikut sertakan toko-toko dari masyarakat yang ahli dalam pembuatan undang-undang tersebut.
\end{abstract}

Kata Kunci : Pengawasan, Tindaka Pidana Korupsi, Lembaga Pendidikan

\section{ABSTRACT}

Supervision conducted Tangerang District Education Office for Preventing Corruption in Institutions of equipment based on Article 66 of Law Nomor.20 of 2003 on National Education System implementation of the supervision by the Government Regulation and Regulation Local Government (LG) in addition District Education Office Tangerang also run surveillance horizontal, supervision Vertical, supervision External, internal oversight, monitoring prevention, surveillance A-Priori, monitoring a-Posteriori, as well as the principles of monitoring and implementing control systems that run continuously in the execution of duties activities in the Tangerang District Education Office. Given the limitations. Legislation governing Corruption in education, while growing, the quantity and quality of educational criminal offense, then the author should suggest to the Government and Parliament. To create a special law on corruption in education.In the manufacture of these laws. By participating deceive legal experts from universities and 
among legal experts as well as to involve other stores of the community who are experts in the manufacture of these laws.

Keywords: Supervision, Corruption, Education

\section{Pendahuluan}

Inovasi Perkembangan ilmu pengetahuan dan teknologi (IPTEK ) adalah salah satu yang mengantar dunia pada era informasi dan globalisasi, di samping memberikan manfaat juga mnimbulkan dampak yang negative bagi kehidupan manusia dan lingkungan. Oleh karena itu perkembangan IPTEK harus direspon positif, inovatif, dan selektif agar dapat memberikan manfaat yang sebesar besarnya bagi umat manusia. Tingkat kemajuan Ilmu pengetahuan dan teknologi yang dicapai oleh bangsa biasanya dipakai sebagai tolak ukur kemajuan bangsa itu.

Perkembangan pendidikan berbasis teknologi informatika dan computer di Indonesia, masih belum oftimal dibandingkan dengan Negara-negara tetangga Singapura dan Malaysia. ${ }^{1}$ Teknologi diciptakan sebagai alat bantu manusia guna mempermudah dalam melakukan pekerjaan. Demikian juga dalam Pendidikan fungsi Teknologi diperlukan dalam upaya meningkatkan mutu pendidikan, maupun ilmu yang lain termasuk ilmu hukum.Produk teknologi informasi, telah menjadi bahagian penting dalam kehidupan manusia, Adanya kemajuan teknologi ini tentu berpengaruh pada berbagai pada sendi kehidupan yang ada dimasyarakat ,baik bidang ekonomi, politik , hukum dan budaya, maupun kehidupan sosial kemasyarakatan lainnya, Hal ini pun berpenggaruh sangat besar dari pola dan tingkah setiap orang dalam aktivitas kehidupannya di masyarakat, kejahatan yang terjadi saat ini, tindak pidana yang dilakukan orang telahmenambah kebeberapa bidang, bidang pemerintah ,bidang pendidikan bidang hukum bidang politik hampir semua lini kehidupan, yang disebabkan pola kehidupan manusia yang ingin memuaskan kebutuhan hidupnya,walaupun tindakan yang dilakukan sudah menyimpang dari norma norma hukum yang ada.

$\mathrm{Di}$ Indonesia, tanggung jawab Negara akan penyelenggaraan pendidikan yang berkualitas bagi setiap warga negaranya diatur dalam pembukaan Undang-Undang Dasar 1945, Alina keempat dan batang tubuh hlm.12.

\footnotetext{
${ }^{1}$ Sutopo,Globalisasi Dibidang Taknologi dan Informasi, Permata Aksara, Jakarta, 2012,
} 
Pasal 31, Dalam pembukaan Undang-Undang Dasar 1945 alinea 4 menyatakan tujuan nasional Negara Indonesia salah satunya“Mencerdaskan kehidupan bangsa Nampak dari pernyataan tersebut bahwa upaya mencerdaskan kehidupan bangsa hanya bisa dicapai melalui Pendidikan. Selanjutnya ditegaskan kembali dalam Pasal 31 ayat (1) Undang-Undang Dasar 1945, bahwa Tiap-tiap warga Negara berhak mendapatkan pengajaran dandalam Pasal 31 (2) dinyatakan bahwa "Pemerintah mengusahakan dan menyelenggarakan satu sistem pengajaran nasional yang diatur dalam satu system pengajaran nasional“

Aparatur pemerintah di Lembaga pendidikan sering bermain terhadap anggaran pendidikan yang sudah di rencanakan tersebut masuk ke kantong kantong aparatur pemerintah yang khusus menggurus anggaran pendidikan tersebut. Korupsi berasal dari bahasa latin Corrumpere, artinya menghancurkan. Menghancur semua bidang. Korup artinya busuk, sogok menyelewengkan uang/barang milik perusahaan atau Negara mengunakan jabatan untuk kepentingan pribadidan Undang-Undang Tindak Pidana Korupsi Nomor 20 Tahun 2001. Pengertian korupsi perbuatan melawan hukum dengan maksud memperkaya diri sendiri atau orang lain yang dapat merugikan keuangan atau perekonomian Negara. tindak pidana yang terjadi di Lembaga pendidikan, yang bernilai dibawah; Rp. 1.000.000.000,- (dibawah satu milyar rupiah) Dalam hal penuntutan ditangani oleh Kejaksaan Negeri. Pengertian dari korupsi disimpulkan bahwa korupsi merupakan tindak pidana yang memiliki unsur-unsur sebagai berikut : Perbuatan melawan hukum, Penyalahgunaan wewenang,kesempatan atau sarana, Memperkaya diri sendiri,orang lain atau korupsi, Merugikan keuangan Negara atau perekonomian Negara Tindak pidana merupakan perbuatan yang oleh hukum pidana $^{2}$ yang dilarang dalam hukum.

1. Tindak Pidana Penganiayaan terhadap murid yang dilakukan di lembaga pendidikan oleh Guru/pendidik

2. Perampasan Kemerdekaan,yang dilakukan di lembaga pendidikan oleh guru/pendidik

3. Penghinaan dan pencemaran nama baik di lembaga pendidikan yang dilakukan oleh guru/pendidik

4. Diskriminasi yang dilakukan guru/pendidik

5. Perbuatan tidak menyenangkan yang dilakukan Guru/pendidik

6. Tindak pidana Asusila dilakukan oleh guru di lembaga pendidikan.

${ }^{2}$ Sudarto, Kapita Selekta Hukum Pidana, Penerbit Alumni, Bandung, 1981, hlm. 45. 
Tindak Pidana Yang diatur diluar KUHP dari Undang-Undang yang lain terdiri dari:

1. Undang-Undang Nomor 23 Tahun 2002 dirubah menjadi, UndangUndang Nomor 35 Tahun 2014. Tentang Undang-Undang Perlindungan anak

2. Undang-Undang Nomor 20 Tahun 2003 Tentang Sisdiknas

3. Undang-Undang Nomor 14 Tahun 2005 tentang Guru dan Dosen. Penyimpangan dan pelanggaran, tindak pidana pendidikan tersebut dilakukan guru, murid/mahasiswa serta penyelenggara Pendidikan itu sendiri,beserta masyarakat luas, seperti : Tindak pidana di Lembaga Pendidikan terhadap dana-dana pendidikan, yang bernilai kurang dari Rp. 1.000.000.000,- (kurang dari satu milyar) yang ditangani langsung dalam hal penuntutan oleh kejaksaan. Berbagai bentuk kekerasan, perbuatan asusila, serta berbagai bentuk pencemaran ataupun penghinaan.

\section{Permasalahan}

Berdasarkan latar belakang yang telah diuraikan tersebut, pokok permasalahan dalam tulisan ini adalah pertama, Bagaimana bentuk-bentuk tindak pidana korupsi pada lembaga pendidikan ? Bagaimana bentuk pengawasan tindak pidana korupsi pada dinas pendidikan di Kabupaten Tangerang ?

\section{Metode Penelitian}

Penelitian ini merupakan sarana pokok dalam pengembangan ilmu pengetahuan. Hal ini disebabkan oleh karena penelitian bertujuan untuk mengungkapkan kebenaran secara sistematis, metodologis, dan konsisten. ${ }^{3}$ Keberadaan setiap metodologi di dalam setiap penelitian dan pengembangan ilmu pengetahuan adalah merupakan suatu unsur yang mutlak harus ada. ${ }^{4}$

\section{Pembahasan}

\section{Bentuk-bentuk Tindak Pidana Korupsi Pada Lembaga Pendidikan}

Landasan Yuridis Sistem Pendidikan Nasional Indonesia adalah seperangkat konsep peraturan perundang-undangan Indonesia yang menjadi titik tolak Sistem Pendidikan Nasional Indonesia.Pancasila adalah Landasan

${ }^{3}$ Soerjono Soekanto dan Sry Mamuji, Penelitian Hukum Normatif, cet 4, PT. Raja Grapindo Persada, Jakarta, 1994, hlm. 1.

${ }^{4}$ Soerjono Soekanto, Pengantar Penelitian Hukum, cet.4, Universitas Indonesia, Jakarta, 1986, hlm. 12. 
Idial dan UUD 1945 adalah landasan Konstitusional dalam Sistem Pendidikan Nasional Indonesia.UUD 1945 yang merupakan landasan utama

Unsur-Unsur tindak pidana yang diatur secara tegas dalam Pasal 67 sampai 71 tersebut lebih cenderung hanya pada tindak kejahatan :

1. Memberikan ijazah, sertifikat kompetensi, gelar akademik, profesi, dan/atau vokasi yang tidak meiliki hak untuk memberikannya.

2. Beroperasinya penyelenggaraan perguruan tinggi meskipun jin operasionalnya telah ditutup

3. Memberikan sebutan guru besar yang tidak sesuai dengan ketentuan undang-undang sistim pendidikan nasional.

4. Penyelenggaraan pendidikan jarak jauh yang menyimpang dari ketentuan undang-undang system pendidikan nasional

5. Membantu memberikan ijazah, sertifikat kompetensi, gelar akademik, profesi, dan/atau vokasi yang tidak memiliki hak untuk memberikannya.

6. Penggunaan ijazah, sertifikat kompetensi, gelar akademik, profesi dan / atau vokasi yang diperoleh dari satuan pendidikan yang tidak sesuai dengan undang-undang sistem pendidikan nasional.

7. Pengunaan gelar lulusan yang tidak sesuai bentuk dan singkatan yang diterimanya dari perguruan tinggi yang sah.

8. Memperoleh dan/atau menggunakan sebutan guru besar yang tidak sesuai dengan undang - undang sistem pendidikan nasional yang berlaku.

9. Pengunaan ijazah, sertifikat kompetensi, gelar akademik, profesi, dan/atau vokasi yang ternyata palsu.

10. Plagiat karya ilmiah.

Pola-pola korupsi di Lembaga pendidikan atau bidang pendidikan sbb:

1. Pembuatan anggaran ganda pada anggaran pendapatan belanja sekolah (APBS) yakni pemungutan dana masyarakat walaupun yang diberikan pemerintah mencukupi.

2. Pungutan liar(pungli) Dana yang diambil tidak adanya hubungi dengan proses belajar

3. Pengelapan dana Bos yang tidak dimasukan pada Anggaran pendapatan belanja sekolah (APBS )

Katagori-Katagori korupsi di Lembaga pendidikan atau bidang pendidikan :

a. Situs suara Merdeka Tanggal 14 Desember 2005, Kepala dinas Pendidikan kota Semarang Drs Santoso,beserta enam kepala sekolah,yakni SMP 1,SMP 10 dan smk 5 semarang diperiksa oleh 
kejaksaan Negeri Semarang,terkait dengan kasus penyaluran dana beasiswa fiktif senilai 40 miliar rupiah.( Tindak Pidana Penipuan)

b. Tempo Pikiran Rakyat Cyber Media tanggal 13 Januari 2005 Indonesia Corruption watch (ICW) melaporkan terjadi korupsi dana pendidikan di Sekolah Dasar percontoan Rawamangun Jakarta, Kepala Kejaksaan Tinggi DKI kasus dugahan korupsi ini telah terjadi sejak tahun 2002 diduga mengakibatkan kerugian ratusan juta rupiah.( Tindak Pidana Pengelapan )

c. Situs Merdeka tanggal 24 Mei 2004 2004,Komisi E.DPRD Kudus diduga melakukan korusi terhadap dana pendidikan tahun 2004 dengan menjalankan data sekolah fiktif penerima bantuan tersebut.(Tindak Penipuan )

d. Situs Bali Pos tanggal 14 Januari,2003,6 (enam ) orang mahasiswa Jurusan Teknik kimia ITATS Surabaya menyuap staf administrasi Fakultas teknik, untuk menhubah nilai dalam transkrip nilai sehingga mereka dapat mengikuti yudisium yang dilangsungkan tanggal 23 November 2003. ( Tindak Pidana Penipuan )

e. Situs ICW (www.antikorupsi.org) bahwa disinyalir telah terjadi penyimpangan dana pembangunan Sekolah SMUN 08 di Kupang senilai 1 miliar rupiah. Pemenfaatan dana pembangunan tersbut tidak jelas dan terpakai meskipun sekolah tersebut belum rampung. (Tindak Pidana Pengelapan).

Berdasarkan hasil riset yang dilakukan ICW pada tahun 2010 terdapat 50 sekolah di Jakarta dan pada tahun 20013, 100 sekolah di Jakarta,Garut dan,Solo yang diindikasikan terjadi praktek korupsi dalamnya.Ketentuan pidana pendidikan yang diatur dalam undang-undang nomor 20 tahun 2003 tersebut di atas, pada dasarnya kurang dapat menjangkau dinamika perkembangan kuantitas dan kualitas tindak pidana pendidikan, karena secara realitas tindak pidana pendidikan itu tidak hanya sebatas kejahatan-kejahatan pendidikan melainkan masih banyak tindak pidana pendidikan yang belum dapat di akomodir dalam Pasal 68 sampai Pasal 71 di atas, misalnya :

1. Penekanan nilai yang dilakukan guru terhadap muridnya

2. Pemaksaan terhadap siswa/mahasiswa oleh oknum pengajar tidak bertanggung jawab, yang umumnya dilaksanakan melalui paksaan baik secara terang-terangan maupun secara tersamar melalui berbagai sikap tindak dan basa-basi yang umumnya disertai dengan berbagai ancaman halus/intimidasi, agar para siswa/mahasiswa memenuhi kemauannya,

3. Berbagai perlakuan tidak wajar dan tidak beralasan yang dilakukan oleh seorang oknum pengajar terhadap muridnya baik secara jasmaniah (misalkan melalui berbagai macam tindakan kasar) maupun secara 
mental (misalkan melalui penghinaan, pengejekan, penggertakan dan sejenisnya yang pada dasarnya bertujuan untuk setidak-tidaknya dapat membunuh semangat/keberhasilan si murid yang bersangkutan).

4. Pengajaran dengan metode dan materi buruk/kadar mutu yang sangat rendah, yang sebenarnya hamper tidak ada manfaatnya bagi murid dan bahkan sebaliknya, malahan membahayakan karena melemahkan murid.

5. Pelaksanaan pendidikan dan pengajaran yang menyimpan dari kebenaran umum tanpa dapat dipertanggungjawabkan oleh pendidik/pengajar yang bersangkutan serta berakibat buruk bagi murid.

6. Pelaksanaan pendidikan dan pengajaran yang menyimpang dari nilainilai moral/ keakhlakan, kesusilaan, hukum, agama/budi-pekerti, tatakrama/sopan-santun dan ketertiban umum yang sewajarnya.

7. Pencurian, pemalsuan atau pembajakan karya ilmiah orang lain dalam bentuk apapun, baik seluruhnya maupun hanya sebagaiannya saja dan termasuk juga dalam hal ini: Pengakuan palsu atas hasil karya/penemuan ilmiah orang lain baik secara lisan ataupun tertulis.

8. Penipuan/pengakuan palsu dari seorang oknum pengajar mengenai jabatan/hasil karyanya yang sebenarnya tidak ada, dengan maksud agar ia dipercaya orang sehingga ia bisa memperoleh sesuatu yang sebenarnya tentu saja bukan menjadi haknya. Sebagai contoh misalkan, perbuatan seorang oknum yang mengaku-ngaku sebagai dosen atau orang yang mempunyai kedudukan serta mengaku pernah membuat sejumlah karya namun tidak dapat dibuktikan secara konkrit, dengan maksud tentunya agar ia bisa memperoleh pangkat yang lebih tinggi di lembaga pendidikan formal di mana ia betul-betul bertugas.

\section{Bentuk-bentuk Pengawasan Tindak Pidana Korupsi Pada Dinas Pendidikan Kabupaten Tangerang}

Pengawasan Jalur Horizontal adanya sub-subdinas yang terbagi menjadi Sub Dinas Pendidikan Dasar, Sub Dinas Pendidikan Umum, Sub Dinas Pendidikan Menengah Kejuruan, Sub Dinas Pendidkan Luar sekolah, Sub Dinas Ketenagaan, Sub dinas Sarana Prasarana dan Bagian umum (Ketatausahaan/TU)

Pengawasan Jalur vertikal.

Kebijakan pemerintah pusat dalam hal ini Departemen Pendidikan Nasional,bersipat koordinatif dan simulative, artinya peran pusat dalam menyelenggaraan program pendidikan sepenuhnya diserahkan kepada daerah. Dinas pendidikan Kabupaten Tangerang juga mempergunakan pengawasan :

1) Pengawasan Internal 
2) Pengawasan eksternal

3) Pengawasan ditinjau dari segi waktunya

a. Pengawasan a-priori atau pengawasan preventif yaitu pengawasan yang dilakukan oleh aparatur pemerintah yang labih tinggi terhadap keputusan-keputusan dari aparatur yang lebih rendah, pengawasan dilakukan sebelum dikeluarkan suatu keputusan atau ketetapkan.

b. Pengawasan a-posteriori atau pengawasan refresif yaitu pengawasan yang dilakukan oleh aparatur pemerintah yang lebih tinggi terhadap keputusan aparatur pemerintah yang lebih rendah,pengawasan dilakukan setelah dikeluarkan keputusan ketetapan pemerintah atau sudah terjadi tindakan pemerintah.ketetapan bisa pencabutan apabila peraturan pemerintah bertentang dengan undang-undang lebih tinggi. ${ }^{5}$

4) Sistem Pengawasan di Dinas Pendidikan Kabupaten Tangerang yang menjadi pokok pikiran dalam penulisan jurnal ini, antara lain:

a. Meningkatkan intensitas dan kualitas pelaksanaan pengawasan dan audit internal dan eksternal dan pengawasan masyarakat khusus di lingkungan dinas Pendidikan Kabupaten Tangerang.

b. Menata dan menyempurnakan kebijakan sistem, struktur kelembagaan dan prosedur pengawasan yang independen, efektif dan efesien transparan dan terstruktur di dinas Kabupaten Tangerang

i. Meningkatkan tindak lanjut temuan pengawasan secara hukum.

ii. Meningkatkan kordinasi pengawasan yang lebih komprehensip

iii. Mengembangkan penerapan pengawasan berbasis kinerja

iv. Mengembangkan tenaga pemeriksa yang professional

v. Mengembangkan sisitim akuntabilitas kinerja dan menorong peningkatan implementasi pada seluruh instansi

vi. Mengembangakan dan meningkatkan sisitim informasi dan perbaikan kualitas informasi hasil pengawasan.

vii. Melakukan eveluasi berkala atas kinerja dan temuan hasil pengawasan. $^{6}$

5) Prinsip Pengawasan yang dilakukan di Dinas Pendidikan Kabupaten Tangerang untuk mencegah terjadi Tindak Pidana Korupsi antara lain :

${ }^{5}$ Ulbert Silalahi, Studi tentang Ilmu Administrasi Konsep Konsep Teori dan Dimensi, Sinar Baru, Bandung, 2002 ,hlm. 79.

${ }^{6}$ Amran Suadi, Sisitim Pengawasan Badan Peradilan di Indonesia, Grafindo persada, Jakarta, 2014, hlm. 213. 
1. Pengawasan harus berlangsung terus menerus bersamaan dengan pelaksanaan kegiatan atau pekerjaan.

2. Pengawasan harus menemukan,menilai dan menganalis data tentang pelaksanaan pekerjaan secara objektif

BOS Adalah program Pemerintah yang pada dasarnya adalah untuk penyediaan pendanaan baiaya operasi nonpersonalia bagi satuan pendidikan dasar sebagai pelaksana program wajib belajar.Menurut Peraturan Pemerintah Nomor 48 Tahun 2008 tentang pendanaan pendidikan,biaya non personalia adalah biaya tak langsung berupa daya,air,jasa telekomunikasi,pemeliharaan sarana dan prasana,uang lembur,transportasi,konsumsi,pajak dan lain-lain.

Tujuan Bantuan operasional sekolah (BOS)

1. Membebaskan punggutan bagi seluruh peserta didik, SD/SDLB Negeri,dan SMP/ SMPLB/ SD/S MP.SATAP/SMPT, terhadap biaya operasional sekolah.

2. Membebaskan pungutan seluruh peserta didik miskin dan seluruh punggutandalam bentuk apapun,baik di sekolah negari maupun swasta.

3. Meringankan beban biaya operasi sekolah yang peserta didik di sekolah swasta.

4. Sekolah berbasis pemerintah dan swasta menerima bantuan dana Bosini akan ada penilainya khusus sekolah yang berbasis swasta ada kreteria penilainya.

Sasaran Program dan besar dana Bantuan

1. Sekolah dengan jumlah peserta didik minimal 80 (SD/SDLB) dan 120 (SMP/SMPLB/Satap). BOS yang diterima oleh sekolah, dihitung berdasarkan jumlah peserta didik dengan ketentuan:

a. SD/SDLB : Rp.580.000,-/peserta didik/tahun

b. SMP/SMPLB/SMPT/Satap: Rp.710.000,- peserta didik/tahun.

2. Sekolah dengan jumlah peserta didik dibawah 80 (SD.SDLB dan 120 (SMP/SMLB/Satap)

Agar pelayanan pendidikan sekolah dapat berjalan dengan baik.

Pemerintah memberikan dana BOS dengan sekolah setingkat SD peserta didik kurang 80 peserta didik dan SMP yang kurang dari 120 peserta didik. ${ }^{7}$ Tapi tidak berlaku dengan criteria sekolah senagai berikut:

a. Sekolah swasta bagi keluarga mampu sehingga telah memungut biaya mahal. 
b. Sekolah tidak diminati oleh masyarakat sekitar karena tidak berkembang sehingga peserta didik sedikit masih terdapat alternative lain di sekitarnya.

c. Sekolah yang terbukti dengan sengaja membatasi peserta didik dengan tujuan untuk memperoleh dana BOS dengan kebijakan khusus tersebut.

Agar kebijakan khusus BOS ini tidak salah sasaran dan menimbulkan efek negative, yang akan terjadi tindak pidana pendidikan dilakukan mekanisme suatu kebijakan unttuk dapat mencegah khusus mengikuti langkah- langkah sebagai berikut:

1. Tim Manajemen BOS, Dinas Pendidikan, kabupaten/kota melakukan tindakan mencegaha dengan jalan melakukan memverifikasi sekolah yang akan mendapatkan kebijakan BOS tersebut.

2. Berdasarkan hasil verivikasi,tim manajemen Dinas Pendidikan. Kabupaten/Kota, mengirim surat kepada Tim manajemen Bos Provinsi dengan melampirkan daftar sekolah mana yang direkomendasikan dan daftar sekolah yang tidak direkomendasikan, dan memberikan data dan jumlah peserta didik ditiap sekolah,diberikan kepada provinsi tersebut rekomendasi satu kali dalam satu tahun.

3. Tim Manajemen Bos Provinsi menyalurkan dana BOS sesuai dengan rekomendasi Tim manajemen Provinsi.Jadi, dana BOS yang diterima sekolah dalam kelompok ini adalah:

a. SD sebesar $=80 \times$ Rp.580.000,- $/$ tahun

$$
\text { = Rp. 46.400.000,-/tahun }
$$

b. SMP/Satap sebesar $=$ sebesar $120 \times$ Rp. $710.000 /$ tahun

$$
=R p .85 .200 .000,-/ \text { tahun. }
$$

Khusus untuk sekolah luar biasa (SLB) terlepas 3 (tiga)

kemungkinan yang terjadi di lapangan:

a. SDLB yang berdiri sendidri tidak menjadi satu dengan SMPB, dana BOS yang diterima sebesar $=80 \times$ Rp.580.000, $-=$ Rp. 46.400.000, /tahun

b. SMPLB yang berdiri sendiri tidak menjadi satu dengan SDLB yang terima sebesar $=120 \times$ Rp.710.000,- $\quad$ Rp. 85.000.200.000,/tahun

c. SLB diterima SDLB dan SMPLB menjadi satu pengelolaan, dana Bos yang ditema sebesar $=120 \times$ Rp.710.000, $-=$ Rp. 85.200.000,/tahun 
Untuk SMP terbuka dan TKB Mandiri, jumlah dana BOS yang diterima tetap berdasarkan jumlah peserta didik riil karena pengelolaan dan pertanggung jawaban dengansekolah induk. ${ }^{8}$

Pengawasan ini dilakukan oleh Dinas pendidikan Kabupaten Tangerang untuk mencegah tidak terjadi tindak pidana korupsi di Lembaga Pendidikan adalah sebagai berikut:

1. Pengawasan ditujukan untuk memantau penyaluran dana, penyerapan

2. dana,dan penggunaan dana di tingkat sekolah,

3. Responden terdiri dari sekolah dan murid dan/atau orang tua murid. Yang dilakukan Tim manajemen Dinas pendidikan Kabupaten dan, salah satu tindak mencegah Tindak pidana pendidikan.

4. Pengawasan dilaksanakan pada saat penyaluran dana dan pasca penyaluran dana,dengan demikian hal mencegah tindak pidana korupsi dibidang pendidikan bisa di awasi.

5. Pengawasan dapat melibatkan pengawasan sekolah

6. Tim Manajemen BOS Dinas Pendidikan KabupatenTangerang memanfaatkan pengawasan sekolah dan bertanggung jawab mencegah dan untuk melakukan monitoring dan mencegah tindak pidana korupsi di bidang pendidikan.

Dalam Undang-Undang Nomor 20 tahun 2003 tentang Sikdinas tidak dijelaskan pertanggung jawab pidana yang dilakukan oleh guru/pendidik hanya menyebut sangsi pidana pada pasal 67 sampai dengan pasal 71 siapa yang melakukan Tindak Pidana Korupsi akan mendapat sanksi pidana baik yang ada dalam undang-undang Nomor 20 tahun 2003 tentan Sisdiknas dan undang-undang Nomor 20 tahun 2001 tentang tindak pidana korupsi,dalam kedua undang-undang tersebut jelas bentuk sanksi masing-masing, yaitu:

a) Pengawasan Dan Pemeriksaan Serta Sanksi Terhadap Dana BOS yang Dilakukan Penyimpang Dikenakan Sangsi Tindak Pidana Korupsi Undang-Undang Nomor 20 Tahum 2001.

1) Pengawasan

Pengawasan dana BOS meliputi pengawasan yang melekat,pengawasan fungsional dan pengawasan masyarakat. 
a. Pengawasan melekat yang dilakukan oleh pimpinan masingmasing instansi kepada bawahannya baik di tingkat pusat maupun,provinsi,Kabupaten maupun sekolah. .

b. Pengawasan Fungsional internal oleh Inspektorat Jendral Kemdidbud serta Inspektorat Daerah Provinsi dan Kabupaten dengan melakukan audit sesuai dengan kebutuhan lembaga tersebut atau permintaan instansi akan diaudit.

c. Pengawasan oleh Badan Pengawasan Keungan dan Pembengunan (BPKP) dengan melakukan audit atas permintaan instansi yang akan diaudit.

d. Pemeriksaan Keuangan (BPK) sesuai dngan kewenangan.

e. Pengawasan masyarakat dalam rangka transparansi pelaksanaan program BOS oleh unsur masyarakat dan unitunit pengaduan masyarakat yang terdapat disekolah,Kabupaten,Provinsi dan Pusat,apabila terdapat indikasi penyimpangan dalam pengelolaan BOS,agar segera dilaporkan pada instansi pengawasan fungsional atau lembagaa berwenang lainnya. ${ }^{9}$

2) Sanksi

Sanksi terhadap penyalahgunaan wewenang yang dapat merugikan Negara dan/atau sekolah dan/atau peserta didik akan dijatuhkan oleh aparat/pejabat yang berwenang. Sanksi kepada oknum pegawai Negeri tersebut yang melakukan pelanggaran dapat diberikan sanksi pada Undang-Undang tindak pidana Korupsi Undang-Undang Nomor 20 Tahun 2001, misalnya :

1. Yang berlaku salah satu undang nomor 20 tahun 2001 tentang tidak pidana korupsi (pemberhentian,penurun pangkat,mutasi kerja,proses hukum)

2. Penerapan tuntutan perbendaharaan dan anti rugi,yaitu dana BOS yang terbukti disalahgunakan agar dikembalikan kepada satuan pendidikan atau ke kas daerah provinsi.

3. Penerapan proses hukum,yaitu mulai proses penyelidikan,penyedikan dan proses peradilan bagi pihak yang diduga atau terbukti melakukan penyimpangan atau tindak pidana korupsi dana BOS.

4. Pembelokiran dana dan penghentian sementara seluruh bantuan pendidikan yang bersumber APBN pada tahun berikutnya kepada provinsi/kabupaten/kota, bilamana terbukti pelanggaran 
tersebut dilakukan secara sengaja dan tersistem untuk memperoleh keuntungan pribadi,kelompak, atau golongan.

Monitoring dan Supervisi yang dilakukan oleh tim Bos Dinas

Pendidikan Kabupaten Tangerang kepada penerima bantuan dari dana Bos,Komponen utama yang dimonitor antara :

1. Alokasi dana sekolah penerima bantuan

2. Penyaluran dan penggunahan dana BOS

3. Pelayanan dan penanganan pengaduan

4. Administrasi keuangan

5. Pelaporan,serta pemajangan rencana penggunaan dan pemakaian dana BOS.

Monitoring dan Supervisi yang dilakukan oleh Dinas pendidikan

KabupatenTangerang merupakan salah satu tindak Preventif mencegah supaya tidakterjadi Penyimpangan terjadi Tindak pidana korupsi terhadap dana Bos.

Larangan Penggunaan Dana Bos :

1. Disimpan dengaan maksud dibungakan

2. Dipinjam kepada pihak lain

3. Membeli software/perangkat lunak untuk pelaporan keuangan Bos.

4. Kegiatan yang tidak menjadi priotas sekolah 


\section{Penutup}

\section{Simpulan :}

Pertama, Kualifikasi Jenis-Jenis Tindak Pidana Korupsi di Lembaga Pendidikan Berdasarkan Undang - Undang Nomor 20 tahun 2003 tentang sistem pendidikan nasional. Dalam isi dari Undang-Undang tersebut, tidak menyebutkan Kualifikasi Jenis -Jenis Tindak Pidana Korupsi. Dalam Bab X isi dariPasal 67 -sampai dengan Pasal 71. Hanya menyebutkan ketentuanketentuan pidana, selanjut dalam Pasal tersebut juga tidak membedakan antara Tindak Pidana Pelanggaran dengan kejahatan.Disamping itu juga Isi daripasal-pasal,tersebut tidak membedakan apakah tindak pidana itu dilakukan oleh siswa, guru, orang tua wali murid atau orang lain, tidak jelas pelaku tindak pidana pendidikan akan berpengaruh dalam pemberian sanksi pidana, disamping tidak mempertimbangkan aspek-asfek dari pelaku pidanajugatidak mencerminkanrasa keadilan.

Kedua, Bentuk Pengawasan yang dilakukan Dinas Pendidikan Kabupaten Tangerang untuk mencegah Tindak Pidana Korupsi di Lembaga ${ }^{10}$ Pendidikan tetap berdasarkan pada Undang-Undang Nomor 20 Tahun 2003 Tentang Sidiknas pasal 66 Tentang Pengawasan,dan di tindak lanjutkan pelaksanaan dari pengawasan tersebut diatur dengan Peraturan Pemerintah dan Peraturan Pemerintah Daerah (Pemda) serta menggunakan pengawasan yang lainnya,yang terdiri dari, Pengawasan Horizontal, Pengawasan Vertikal, Pengawasan Eksternal, Pengawasan Internal, Pengawasan a.priori, Pengawasan a-posteriori dan Pengawasan Preventif,

\section{Saran :}

Pertama, Adanya keterbatasan peraturan perundang-undangan yang mengatur tindak pidana dibidang pendidikan,khusus tindak pidana korupsi di bidang pendidikan, dan semakin berkembangnya kuantitas dan kualitas tindak pidana pendidikan maka penulis menyarankan,pada Pemerintah dan DPR untuk membuat Undang-Undang Khusus tentang Tindak pidana korupsi di bidang Pendidikan.

Kedua, Dalam tindak lanjut pembuatan Undang-Undang Tindak Pidana Korupsi di bidang pendidikan tersebut.Dengan ikut memperdayakan pakarpakar hukum dari Perguruan Tinggi dan kalangan Pakar hukum lainnya 


\section{Daftar Pustaka}

\section{Buku}

Adami Chazawi, Kejahatan Terhadap Harta Benda, IKIP, Malang, 1995.

Andi Hamzah, Asas-Asas Hukum Pidana, Rineka Cipta, Jakarta,1944

Bemmelem, MR.J.M. Van, Hukum Pidana I,Bina Cipta, Bandung, 1987.

Barda Nawawi Arief, Makalah“Konsepsi Ajaran Sifat Melawan Hukum, 2004.

Farid, A.Zainal Abidin, Hukum Pidana I, Sinar Grafika, Jakarta, 1995.

Indriyanto Seno Adjie, Makalah Seminar Nasional "Asas Perbuatan Melawan Hukum Material Dan Masalahnya Dalam Perpektif Hukum Pidana di Indonesia". Semarang, 2004.

Noorsyam, Pengertian dan Hukum Dasar Pendidikan (Dalam Buku yang berjudul: Pengantar Dasar-Dasar Kependidikan), Usaha Nasional, Surabaya, 1890.

Ridwan Halim,.1984. Tindak Pidana Pendidikan Suatu Tinjauan Filosofis Edukatif, Ghalia Indonesia, Jakarta, 1984.

Rudolf Dreikurs, Disiplin Tanpa Hukuman, Remadja Karya, Bandung, 1984.

Rony Kontur, Metode Penelitian, PPM, Jakarta, 2004.

Sudarwan Danim, Agenda Pembaharuan Sistem Pendidikan. Yogyakarta, Pustaka Pelajar, 2003.

Sanapiah Faisal, Fungsi Sekolah Sebagai Lembaga Sosial (dalamBuku: Pengantar Dasar-Dasar Kependidikan), Usaha Nasional, Surabaya,

Soegarda Poerbakawatja, Ensiklopedia Pendidikan, Gunung Agung, Jakarta, 1980.

Teguh Prasetyo, Politik Hukum Pidana, Pustaka Pelajar, Yogyakarta, 2005.

Wirjono Prodjodikoro, Hukum Acara Pidana di Indonesia, Sumur, Bandung, 1962. 